\title{
How Much Competition Do We Need in a Civilized Society?
}

\author{
Review of "WINNING; Reflections on An American Obsession" \\ by Francesco Duina, Princeton University Press, Princeton and \\ Oxford, 2011, ISBN 978-0-691-14706-2
}

\author{
Jan Ott \\ Published online: 3 March 2011 \\ (C) The Author(s) 2011. This article is published with open access at Springerlink.com
}

\section{Introduction}

Francesco Duina is an American associate professor and chair of the Sociology Department at Bates College, in Maine, USA, and visiting professor at the International Center for Business and Politics in Copenhagen, Denmark. His latest book "Winning" is about the American love for competition; a love not shared by all Americans, but dominant enough to shape how many Americans live. In the rest of the world, and certainly in more egalitarian nations like Denmark and the Netherlands, people have more reservations about competition (Data World Values Surveys). Duina describes the "American obsession" with competition and winning and losing very vividly. The bulk of the book is descriptive but in the last chapter Duina makes some critical normative remarks and proposes an alternative mind-set for the USA. This book is important because it poses the question how much competition we really need in rich nations, with high levels of economic and cultural productivity. The answer to this question is relevant in discussions about the role of governments and about the optimal levels of liberalization or regulation of markets. Duina's suggestions to moderate and redirect competition by changing the American mind-set are valuable. His suggestions might have been more adequate, however, if he would have made a distinction between 'competition for fun' and 'competition to survive', and if he would have paid more attention to their different effects on happiness.

\section{Duina's Book}

\subsection{Direct and Indirect Effects of Winning}

Duina identifies some less obvious effects of competition. The American love for competition is more than love for winning and dislike of losing. Spectators are interested in the thrill of uncertainty about the outcomes and about the subtle pleasures of watching

J. Ott $(\bowtie)$

Erasmus University Rotterdam, Rotterdam, The Netherlands

e-mail: jan.ott@planet.nl 
struggling and suffering. The competitors themselves are motivated by the desire to distinguish themselves. But more is at stake. In Chapter Eight: 'Injecting Value', Duina presents a comprehensive list of the positive effects of winning: 'the prize ladder' (p. 141). On the first three steps there are prizes directly related to the competitive event: intrinsic, associated and derivative prizes. On the highest two steps there are prizes injected from the outside for the competitors and the community respectively. These prices are about prestige, honour and general superiority; not just for the competitors but also for a community if this community is represented by the winners. Here we are dealing with meanings attributed to victory and loss, in terms of ideas, images and notions. Winning often serves as an objective validation that winners and their communities are right (Chapter Three: "I win, therefore I am right"). Winners are supposed to have a better grasp, not only on the competitive event itself but also on the world in general. Loss, by contrast, raises questions about the way losers approach the world. This explains the fact that victories in sports, like national victories in soccer or at the Olympic Games, are highly appreciated. Some of these indirect prizes are related to religion. According to the General Social Survey more than $75 \%$ of Americans believe that God plays a role in shaping their success or failure. With victory comes the belief that God was instrumental in shaping their performance. People assume consciously or subconsciously that if they win God rewards them for something that they are doing right, not just in the particular realm in question but in life in general. People believe they win because they are worthy of God's grace and are living a virtuous life in line with God's desires (Chapter Eight, p. 145). On p. 182, Duina-speaking for the Americans-summarizes as follows: "If we put these 'prizes' together we see that we are fighting for something of profound importance: our proper place in the world. We do not have or know that place. Through victory, we hope to find it. Loss sends us merciless back to the drawing board-unsure, once more, of who and what we are".

\subsection{Advantages of the Competitive Mind-Set}

In the last chapter (10) Duina identifies some advantages and problems related to the American obsession with competition. This mind-set generates intensity and determination; Americans do not stop to contemplate, they are instead constantly and resolutely working toward their next victory. It would be a mistake in Duina's view to dismiss this attitude as superfluous or irrelevant. With this mentality Americans are more likely to accomplish impressive feats and to earn the respect of others. The competitive mindset also fills life with meaning and relieves people from the painful task of wondering how they should mobilize themselves. There might be other ways but the competitive mind-set seems to be doing a good job for vast numbers of people: their lives have purpose and a direction. Another advantage has to do with entertainment. A good dose of uncertainty infuses most competitive events. People experience pleasure in being exposed to the possibility of failure, because it gives victory its real flavor.

\subsection{Problems of the Competitive Mind-Set}

Duina also identifies problems. The obsession is very exhaustive for several reasons. It generates enormous tensions, first of all because of its adversarial nature. A competitive mind-set assumes a position of aggressiveness toward the world. This would be harmless if people were thoughtful and selective about competition, but unfortunately it is deployed without much thought in countless areas. This means that people are seldom at peace with 
the world. The competitive mind-set can be fruitful, but it also generates considerable anxiety and emotional imbalance. The language of winning and losing is also exhausting, because it introduces an element of deep uncertainty in life. As long as people view their activities as tests of their worth, they will be doubtful about themselves. This is also problematic since this mind-set demotivates people to think about their wants and activities, independent of winning or losing. The result is that what comes out of competition does not satisfy people in any definitive way; it just makes them uneasy.

\subsection{A New Mind-Set: How to Change the American Obsession}

Duina believes that the process of self-discovery, followed by the pursuit of activities that match people's true inclinations and desire, is fundamental for the flourishing of the individual. This belief is his starting point to identify three possibilities to change the American mind-set.

(a) Conceptual hygiene. The Americans should use the language of winning and loosing only when they really want to pursue victory at something, in all other cases they should avoid using it. Parents should not view their children applying to colleges as winners nor losers but as young people looking for a way to receive a good college education. People should no longer think of defeated political candidates as losers who should exit the scene as fast as possible but, instead, as people who tried extremely hard to pursue something that clearly mattered to them.

(b) Discovery. The Americans should spend more time and energy discovering what lies behind their love of winning, fear of losing, and in general their embrace of competition. This would generate personal lists but with some general patterns. One general driver is the desire for the admiration of others. Two other general drivers are our need to accomplish something and our need to get to know ourselves. It is important to understand such legitimate needs as something that should be taken seriously. The message is that people should take time to discover what really moves them, in order to be more accurate in the selection of activities.

(c) Alignment. The Americans should match their real drives with activities that best suit them. This may have very little to do with competition. Alignment means establishing a proper relationship with the outer world; a relationship that is honest, direct and purposeful. By alignment people will see their activities as a reflection of themselves. They will be more respectful of others and the things around them as well. Rather then assuming an antagonistic stance towards the world they will be peaceful. Rather then being against something they will be with something. Their activities will originate from a place of affirmation and not fear.

\section{My Comments}

\subsection{Competition: Sometimes for Fun, but Often Inevitable to Survive}

One important conclusion in happiness-research is that people are happier if they use and develop their capabilities. In that respect competition has in general a positive effect on happiness because people are stimulated precisely to do so. In the former communist nations in Eastern-Europe competition was at low levels and this is one of the explanations for their low levels of happiness. Fair competition is also an important counter vailing power against 
corruption and nepotism. If, however, competition between individuals is about crucial conditions and commodities then there are also some substantial negative effects in terms of anxiety and stress. It is therefore useful to distinguish voluntary 'competition for fun' like competition in (amateur) sports from involuntary 'competition' to survive, like competition for money, by finding a job, or by earning a profit as an entrepreneur, to pay for food, housing, medical care and education. To participate voluntarily in some competition for fun is not the same as struggling for such necessities for yourself or your children. Duina makes no such distinctions but seems to be primarily dealing with competition for fun. On p. 167 he writes: "But in most cases the competitors believe in the urgency of an improvement. Sometimes such urgency may be entirely justified. An unemployed single parent with two children to feed has reasons to want to beat other applicants for a job." I fear that the qualification 'sometimes' is somewhat too optimistic and that in many situations people in the USA have very good reasons to beat competitors for jobs, promotions, and profits.

\subsection{Reduce, First of All, The 'Competition to Survive'!}

Duina is rather optimistic-typical American!-about the possibilities to change the American obsession with winning. This obsession or mind-set is a cultural or psychological reality, more or less comparable with the 'social character' as defined by Fromm (1942). Such cultural realities are usually embedded in the social structure of a society and not so easy to change. But perhaps Duina overlooks one interesting option to fulfil his ambition. Only competition for survival has negative side-effects, in addition to the positive effects of competition in general. Reducing competition for survival specifically is therefore an interesting option, in addition to changing competition in general. If this option works it would also make the remaining competition more sympathetic and acceptable, and probably easier to be changed. This approach is less ambitious, but even then rather complicated. People in the USA have to compete for survival in many situations, because they cannot rely on any substantial social support in case of emergencies, like accidents, unemployment, disability or illness. Americans have to compete therefore to create some minimal security on their own, not just for themselves but also for their families. It is not so easy to change this either, but this is exactly what the Danes have accomplished.

\subsection{Why are Danes Happier?}

Duina compares the USA and Denmark, but seems to be reluctant to evaluate the fact that average happiness is much higher in Denmark than in the USA. In 2006 average life-satisfaction was 8.00 in Denmark and 7.26 in the USA on a 0-10-scale (Veenhoven 2010a). One plausible explanation is that the quality of governments is higher in Denmark. ${ }^{1}$ There is, in general, a very positive relation between the technical quality of governments and average

\footnotetext{
${ }^{11}$ For 2006 Denmark and the USA respectively got the following scores for four aspects of the technical quality of government: Government effectiveness 2.32 and 1.53 ; Regulatory Quality 1.86 and 1.63 ; Rule of Law 1.95 and 1.57; Control of Corruption 2.35 and 1.26 (standardized scores between -3.00 and +3.00 ; World Bank, Kaufmann et al. 2008). An interesting finding in this context is that the relation between the size of government and average happiness depends heavily on this technical quality of governments (Ott 2010). Big government in terms of government consumption, expenditures and transfers and subsidies, adds to happiness if this quality is good enough. The quality of government in the USA is lower than in Denmark but still relatively high. More government might produce more happiness in the USA, if this quality is at least maintained!
} 
happiness in nations (Ott 2010). It is plausible therefore that average happiness is higher in Denmark because of better government. This explanation is supported by the fact that the quality of government and average happiness went up in Denmark in the last 20 years, while the USA stayed stationary at lower levels at both points (Veenhoven 2010b). As a consequence, collective conditions and commodities are at a higher level in Denmark. Such conditions, like some minimal job- and income-security and facilities for education, employarility and parental leave, create stability and predictability and make it possible for the Danes to develop and implement their own individual life-plans. This is real freedom and this is important for happiness, because it creates the best possible opportunities for an optimal development of capabilities; or, in Duina's terminology: it facilitates the process of self-discovery, followed by the pursuit of activities that match people's true inclinations and desire.

\section{Conclusion}

The suggestions of Duina to reduce the negative effects of the American obsession are sound and constitute excellent advice for people who are obsessed with competition, in the USA or elsewhere. Such a change, however, is difficult to accomplish and perhaps less urgent as far as competition is voluntarily and for fun. Diminishing the involuntary competition for survival specifically is therefore and additional option. This type of competition has the most negative impact on happiness, by creating anxiety and stress. Several nations, and Denmark in particular, have developed some interesting effective policies in this respect.

Open Access This article is distributed under the terms of the Creative Commons Attribution Noncommercial License which permits any noncommercial use, distribution, and reproduction in any medium, provided the original author(s) and source are credited.

\section{References}

Fromm, E. (1960). The fear of freedom. London: Routledge \& Kegan Paul Ltd.

Kaufmann, D. et al. (2008). Governance matters VII: Aggregate and individual governance indicators, 1996-2007. World Bank Policy Research Working Paper No. 4654. Available at SSRN: http://ssrn.com/abstract=1148386. Data available at: www.govindicators.org.

Ott, J. C. (2010). Good governance and happiness in nations: Technical quality precedes democracy and quality beats size. Journal of Happiness Studies, 11, 353-368.

Veenhoven, R. (2010a). World database of happiness, distributional findings in nations, Erasmus University Rotterdam. http://www.worlddatabaseofhappiness.eur.nl/hap_nat/nat_fp.php. Accessed Jan 2010.

Veenhoven, R. (2010b). World database of happiness, time trends, Erasmus University Rotterdam. http://www.worlddatabaseofhappiness.eur.nl/trendnat/framepage.htm. Accessed Jan 2010. 